\title{
Correction to: The use of Modified Rio score for determining treatment failure in patients with multiple sclerosis: retrospective descriptive case series study
}

\author{
Mesude Tutuncu ${ }^{1}$ (D) Ayse Altintas ${ }^{2} \cdot$ Burcu V. Dogan ${ }^{1} \cdot$ Ugur Uygunoglu $^{3} \cdot$ Nilufer Kale Icen ${ }^{4} \cdot$ Ayse Deniz Elmali $^{6}$. \\ Eda Coban $^{1} \cdot$ Bengi G. Alpaslan ${ }^{3} \cdot$ Aysun Soysal $^{1,5}$
}

(c) The Author(s) under exclusive licence to Belgian Neurological Society 2022

\section{Correction to: \\ Acta Neurologica Belgica (2021) 121:1693-1698 https://doi.org/10.1007/s13760-020-01476-2}

The 6th author name and affiliation was incorrectly published in the original publication. The complete correct name and affiliation is given below.

Ayse Deniz Elmali

Affiliation: Istanbul University, Istanbul Faculty of Medicine, Neurology Department, Istanbul, Turkey

\begin{abstract}
Also, the last author name was spelled incorrectly in the original publication. The complete correct name should read as follows
\end{abstract}

\section{Aysun Soysal}

The original article has been corrected.

Publisher's Note Springer Nature remains neutral with regard to jurisdictional claims in published maps and institutional affiliations.

The original article can be found online at https://doi.org/10.1007/ s13760-020-01476-2.

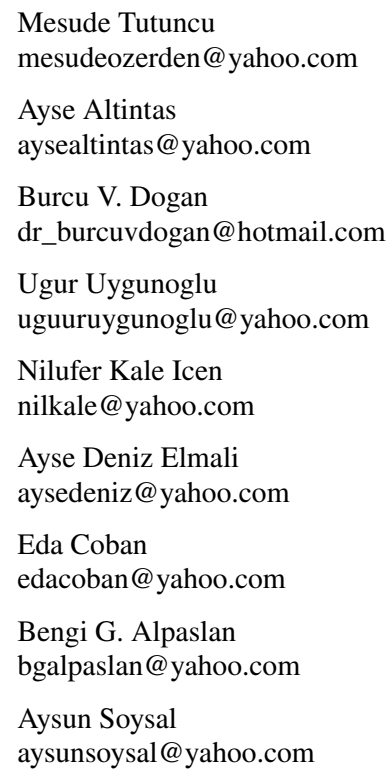

Bakirkoy Prof. Dr. Mazhar Osman Training and Research Hospital for Psychiatry and Neurological Disorders, Zuhuratbaba Mah. Bakirkoy Ruh Sağlığı Ve Sinir Hastalıkları Hastanesi, bitam binasii 3, Noroloji kliniği Bakirkoy, 34147 Istanbul, Turkey

2 Koc University Medical School, Topkapı, Koç Üniversitesi Hastanesi, Davutpaşa Cd. No:4, 34010 Zeytinburnu/İstanbul, 34200 Istanbul, Turkey

3 Cerrahpasa School of Medicine, Cerrahpasa mahallesi, Kocamustafapasa cad. No: 34/E Noroloji Klinigi Fatih, 34200 Istanbul, Turkey

4 Bagcilar Research and Tarining Hospital, Merkezmah. Dr. Sadık Ahmet Cad. Bagcılar, 34100 Istanbul, Turkey

5 Neurology Department, Bakirkoy Prof. Dr. Mazhar Osman Training and Research Hospital for Psychiatry and Neurological Disorders, Zuhuratbaba mah. Bitam Binas1, doktor odası. Bakirkoy, Istanbul, Turkey

6 Neurology Department, Istanbul Faculty of Medicine, Istanbul University, Istanbul, Turkey 